\title{
ЖУРНАЛЬ
}

\section{АКУШЕРСТВА И ЖТННСКИХЪ БОЛЪЗНЕЙ,}

органъ Анушерско-Гинениоогическаго Общества въ С.-Петеруургі.

\section{ГОДЪ СЕДЬМОЙ.}

\author{
МАЙ 1893, № 5 .
}

\section{ОРИГИНАЛЬННЯ СТАТЬИ, ЛЕКЦШИ, КАЗУИСТККА.}

IX.

\section{КЪ УЧЕНІЮ О ВНБМАТОЧНОЙ БЕРЕМЕННОСТИ (ПРИКРБП- ЛЕНІЕ ПЛОДА КЪ ФИБРОЗНОЙ ОПУХОЛИ).}

Прив. доц. А. Н. Соловьева.

(Читано 19 марта 1893 г. въ засьданіи Московскаго Хирург. Общества).

5 февраля сего года я быль приглапенъ г.т. врачами С. $Ө$. Манъжовскимг и $H . A$. Сквориовз८мг для совьта по поводу одного слүчая вньматочной беременности. Наканунь, т. е. 4 февраля у больной, жены офицера, г-жи Х., было внутреннее кровотеченіе, посль котораго развилась острая анемія съ потерей пүльса и обморочнымъ состояніемъ. Благодаря принятымъ со стороны r.r. врачей мьрамъ, пүльсъ у больной появился и съ 3-хъ часовъ утра держался на извыстной высоть отъ 120130 въ 1 м. Я увидал'ь больную около 1 часа дня. 0на была мадокровна, наружные покровы съ желтоватынь оттьнкомъ, видимая слизистая оболочка почти бълаго цвьта, пульсь крайне слабаго наполненія, около 130 въ 1 м. Животь сильно вздүтъ, бользненъ при дотрогиваніи. При внүтреннещъ изсльдованіи задній сводъ ньсколько напряженъ, матка вяла, пріоткрыта. Изъ ея полостп выдьляется кровь съ небольшими клочьями ткани, сходной съ decidua. Больная въ сознаніп, жалуется на чүвство стьсненія въ груди, тошноту и жажду.

Изъ анамнеза, любезно доставленнаго мнь докторомъ С. $\theta$. Маньковскимъ видно, что бодьной 33 года, первыя регулы получила на 15-мь году; менструировала всегда правильно, черезъ 17 дней и по 5-6 дней. Замужь вышла на 18 году, До настоящаго забольванія имьла двое родовъ; роды были правильны, посльдніе около двухъ ль'ть тому назадъ.

До замужества страдала болями въ области сердца, которыя псчезли отъ пріемовъ бромистыхъ солей. Однимъ изъ главныхъ страданій больной 
какъ до замужества, такъ и посль вего-это внезапно появлявшіяся пи скоропроходящія, схваткообразныя боли въ животь, доводившія больную чүть-ли не до обмороковь. Въ 1886 году, сльдовательно еще въ дъвушкахъ, боли эти были настолько сильными, что пришлось прибьгнуть кь врачебной помощи, при чемь больная пролежала ньсколько дней. Причины этихь схватокь врачами тогда ощредьлены не были. Кромь того больная страдала неправильностями со стороны желудочно-кишечнаго канала, выражавшимися то запорами, то поносами. Сонъ быль всегда тревожнымъ. Въ общемъ больная никогда не пользовалась хорошимъ здоровьемъ.

Мать больной жива и здорова. Отецъ умеръ въ преклонномъ возрасть оть страданія печени. У бабушки и матери было много дытей п всь роды были правильны.

Во время настоящей третьей беременности г-жа Х. чувствовала себя лучше, чьмъ в' предшествовавшія, такъ какъ тошнота и рвота были не такъ сильны п продолжнтельны, какъ предъидүщія. Виьсто этого настоящая беременность сопровождалась болями вз ливой стофони низа живота. Больная считала себя беременною на пятомъ мьсяць.

3-го февраля вечеромь г-жа Х. подняла своего ребенка и, почувствовавъ внезапную боль внизу живота, легла. Пролежавъ нькоторое время, по успокоеніи болей поьхала въ гости, гды танцовала.

4-го февраля, т. е. на другой день до 10-ти часовъ утра чувстьовала себл здоровою, возилась около комода до тьхъ поръ, пока выдвинувъ ящикъ внезапно почувствовала головокруженіе, сейчась же легла въ постель. Прпглашенный врачь Н. А. Скворцовъ нашель больную безъ пульса, съ полной картнной остраго малокровія. Въ 3 часа пріфхаль домашній врачъ С. $\theta$. Маньковскій, который нашель больную сь появившпмя пүльсомъ. Льченіе состояло въ подкожныхь впрыскивапіяхъ возбуждающихъ средствъ. Съ часа ночи производились впрыскиванія подъ кожу въ области груди бизіологическаго раствора поваренної соли, всльдствіе чего въ мьсть́⿱宀 впрыскиванія появилась довольно значительная пигментація кожи, въ виль темно-бураго цвЊта пятна, величиною въ ладонь. Черезъ часъ посль начала впрыскиваній поваренной соли, пульсь значительно оправился, сдьлался хоропо прощупываемымъ и больнал окончательно пришла въ сознаніе. Еще съ 11-ти часовъ ночи рњзко выступили явленія peritonitidis, въ видњ сильнаго вздутія живота, его бользненности при дотрогиваніи и повторной рвоты.

Что касается до діагноза, то уже присутствовавшіе до меня врачи С. $\theta$. Маньковскій и Н. А. Скворцовъ опредьлили внутреннее кровотеченіе, всльдствіе разрыва плодовмьстилища при эктопической беременности. Этоть діагнозъ быль подтвержденъ микроскопическимъ изсдьдованіемъ выдьлившихся съ кровью обрывков'ь ткани, оказавшихся по строеніғо кусками отпадающей оболочки.

Какъ уже выше сказано, я быль приглашенъ товарищами для совмьстнаго рьщенія вопроса о дальныйшемь льченіи больной, т. е. держаться ли выжидатедьнаго способа льченія или же приступить къ лапаротоміи для удаленія плода, находящагося вњроятно въ брюшной полости. 
Такъ какъ о переьзды больной въ какое либо, подходящеө для операціи, помњщеніе не могло быть и рьчи, тор л предложиль операцію, отложпвщи ее до сльБующаго дня, если больная доживеть или по крайней мьрь если состояніе ея не ухудшится. Предпринимать лапарогомію въ частной, довољьно тьсной квартирь можно было конечно приготовивши хотя бы одну кощнату, сообразно съ нашими требованіями.

Съ этою цълью одна, самая большая п болье свьтлая комната была переклеена новыми обоями, а въ день операціи, въ теченіи двухъ часовъ опылялась парами карболовой кислоты (посредствомъ пароваго Spray).

0коло 1 часа по полудни 6 февраля приступлено къ лапаротоміи съ помощью докторовъ С. Ф. Маньковскаг, Ф. 0. Ратомскаго, И. М. Серебровскаго и Н. А. Скворцова. Больная легко захлороформировава. Инструменты были опущены въ $2 \%$ растворъ acidi carbolici, а перевязочный матерьяль быль мною привезенъ стерилизованнымъ.

Посль разрьза брғошныхъ стьнокъ до брғошины, черезъ посльвднюго можно было видътьь просвъчиваюицую темнаго цвъта кровь, свободно лежавшую въ полости живота. Брюшина вскрыта въ нижнемь углу раны по зонду, посль чего введенными въ рану двумя пальдами я могь прощупать мелкія части плода, свободно лежавшаго въ полости живота на уровнь входа въ тазъ.

Вскрывши орюшшину кверху, я извлекъ зародышъ наружу, прп чемъ онъ оказался завернутымъ въ оболочки. Пуповина отдьлилась отъ мьста своего плацентарнаго прикрџпленіл. Затьщъ удалено большое количество темныхъ сгустковъ крови, носль чего удалось прощупать съ львой стороны матки въ области фаллопіевой трубы, довольно плотное тьло, величиною въ средній лимонъ, съ одною пероховатою поверхностью, обращенною въ полость живота и кверху; къ этой пероховатой поверхности повндимому прикрьплялась пүповина. Это тьлло было выведено наружу п оказалось снабженнымъ довольно шпрокою ножкою. Япчнпкъ оказался неувелпченнымъ в гладкимъ. Сбоку опухоли въ верхней ея части вамьчена, болье темнаго цвыта, тесьма, толщиного въ гусиное перо, прпнятая нами за часть фаллопіевой трубы.

Имъя въ виду слабость больной, мы не теряли времени для больве подробнаго осмотра и приступили къ удаленію вышеупомянутаго плотнаго тьыла. При перевязкь широкой ножки лигатурами оказалось, что наружные ея края держатся лигатурами крьпко, между тьмъ какъ промежуточная болье тонкая часть ножки (lig. latum) прорпзыьваласъ лигатурами при мадийиемз ихв затягиваніи.

Посль продолжительныхъ попытокъ все таки удалось наложить здъсь лигатуры, хотя уже очень глубоко. Эта ткань, т. е. пирокая связка была очень отечна, ломка, напоминая свойства злокачественнаго новообразованія при наложеніи на него лигатуръ. Помимо частичныхъ лигатурь en masse на кровоточащій участокъ ножки наложенъ еще обвивной шовъ.

Остановивши кровотеченіе, мы приступили къ промыванію полости брюлшины нормальнымъ растворомъ поваренной соли, при чещъ удалено еще 
громадное количество сгустковъ, лежавпихъ между петлями гонкихъ пипекъ и затьмъ полость брюшины осушена стерилизованными салфетками. Серозная оболочка, сильно растянутаго газами кишечника гредставлялась блестящею и төмн0-краснаго щвЊта.

0перація окончена введеніемъ дренажа въ нижній уголъ брюшной раны II закрытіемъ ея тремя глубокими металлическими и нЊсколькими телковыми, поверхностными швами. Повязка изъ іодоформенной марли и стерилизованной ваты, укрђпленной марлевыми бинтами. Вся операція вмъстњ съ хлороформированіемь продолжалась около часа.

Послпоперачіоннъий періодл. Въ теченіе полутора сутокъ изъ дренажа. выдъ̆лялось довольно значительное количество кровяной жидкости; на третій день оно почти совсьмъ прекратилось. Метеоризщъ все болье и болье увеличивался, сопровождаясь рвогою, вщъсть съ которою однажды выдъ̆лилась круглая глиста (asc. lumbric.); рвотныя изверженія имВли каловый запахъ. На третій день поставлена клизма, съ которою вышло довольно значитөльно количество газовъ. На 4-й день самочувствіе больной довольно недурно; тещпература въ теченіе всего времени не достигала 37,0 , но пульсъ голебался между 110-130 ударами въ 1 м. Рвота продолжается. Брюшная рана чпста.

На пятый день я пріњхаль къ больной для перемьны повязки. Оказалось. что въ ночь, при явленіяхъ рвоты, наступиль колляпсъ; метеоризмъ усцлился, температура 36,5, больная бредитъ, пульсь слабъ. Къ вечеру больная скончалась. Аутопсіи не было.

Представляя вниманію Общества описаніе этого случая, я позволю себь коснуться льченія эктопической беременности посли разрыва плодовмъстилища.

Какъ извъстно не всъ врачи согласны между собою относительно времени, когда сльдууеть приступать кь лапаротоміи для пзвлеченія плода изъ брюшной полости при разрыв'ь плодоваго мъшка, т. е. сейтасьь же посль разрыва или же, сообразуясь сь симптомами, вызванными этимъ явленіемъ. Рњшеніе этого вопроса однако весьма существенно, потому что случаи эктопической беременности, представляющіеся наблюденію врачей все болье и болье учащаются. Чъмь объяснить это явленіе-сказать очень трудно, хотя нужно думать, что оно обязано усовершенствованію нашихь діагностическихь пріемовъ съ одной стороны и увеличенію нашихъ научныхъ свъдъній съ другой. Въ доказательство можно привести напримьръ факть, что рядомъ съ учащеніемъ наблюденій случаевь эктопической беременности все рћже и рбже приходится слышать и видбть случаи такь называемый haematocele retrouterina. Смшшеніе посльдняго забольваніи съ внь'- 
маточною беременностью в'ь недавнее прошлое время можно считать очень возможнымъ и вћроятнымъ, хотя у нась и нбть цифровыхь данныхъ, которыми можно было бы доказать это предположеніе.

Играеть ли роль въ большей частоть наблюденій случаевъ внъматочной беременности-учащеніе забольваній женской половой сфреры, въ видт воспалительныхь процессовъ какъ самихь трубъ и яичниковъ, такъ и окружающей ихь кльтчатки - сказать сь положительностью нельљя. Причиною этого также служить отсутствіе данныхъ для сравненія указанныхъ забольваній между собого въ настоящее и прошедшее время. Въ самомъ джль, какимг образомь доказать напримръ, что гоноррейныя забольванія встрбчаются теперь чаще, чьъмь прежде, какъ это предполагають н'бкоторые из'ь врачей.

И такь, по нашему мнбнію, больше въроятія пмиеть за себя объясненіе, тто сь раљвитіемь медицинскихь свъдыній съ одной стороны и усовершенствованіемъ напихъ діагностическихъ пріемов' съ другой, мы можемъ лучпе ставить діагнозь эктопической беременности.

Несмотря однако на все это можно сказать, тто случаи несомнюнной діагностики внжматочной беременности встрғьаются сравнительно нечасто. Смъшеніе этого явленія в'ь первые м'сяцы съ опухолями трубъ, яичников' и окружагоей ихь кльтчатки въроятно неръдки, особенно тогда, когда эктоцическая беременность рано прекрапаеть свое развитіе, всльдствіе смерти зародыша. Такіе случаи при отсутствіи у больной какихъ либо симптомовъ, вызываемых'ь этимь состояніемь, должны ускользать оть наблюденія врачей.

Что же касается до діагнова эктопической беременности посль разрыва плодовм'стилища, то въ настоящее время онъ въ большинствъ случаевъ представляется не особенно труднымь, если мы будем' им'ьть дҺ̈ло съ внезапно появившейся острой анеміей у больной, считавшей себя беременной,

Когда врачъ встрбчается съ такимъ чистым' случаемъ, какь это было напр. въ нашемъ, то первою задачею будутъ заботы объ устраненіи вызваннаго внутренним'ь кровотеченіемъ пока и остановка этого посльдняго, а второю-предупрежденіе перитонита. 
И то, и другое происходить иногда силами природы, что и служить причиною того, что существують защитники выжидательнаго метода льчченія. Несомнъ̆нно, однако, что смертность при этомь способћ льченія громадна.

Для трубной беременности напр. по Hecker'у ${ }^{1}$ ) эта смертность равняется приблизительно $100 \%$, потому что изъ собранныхъ имь 53 случаевъ выздоровьла только одна больная, которая въ 1848 г. забольла признаками внутренняго кровотеченія, а в'ь 1854 году, посл'ь смерти оть гангреновной пневмоніи, трупъ ея подвергся вскрытію, произведенному проф. $R$. Virchow'ымъ; при этомь въ полости живота найденъ litopaedion посль трубной беременности.

Въ нашей литературћ мы имкемъ работу Змигродскаго $^{2}$ ), въ которой сдълань очень полный обзорь всъхь сочиненій по вопросу об́ь эктопической беременности Изъ этого обзора видно, что попытки къ уменьпенію выпеуказанной громадной смертности путемь болье рапіональнаго личченія относятся ко второй половинй текущаго стольитія.

Какъ я уже сказаль зыпе, мы здъсь не будемъ касаться вопроса льченія внћиаточной беременности до разрыва плодовмбстилица, гдъ при несомнжнной діагностикъ подобнаго страданія существуютъ различные методы, клонящіеся главнымъ образомъ къ умерщвленію плода, хотя, по напему мнбнію, оперативное удаленіе будеть напболье раціональнымъ. Справедливость посльдняго доказывается данными, полученными, напр., Д.. О. Отмомб ${ }^{3}$ ).

По изсльдованіямь $K$. Змигродскаго видно, что до 1875 года никто нө р'ьшался приступать къ пропвводству такой рискованной операпіи, при чемъ у Parry встрбчается выраженіе, что до самаго посльдняго времени раздавались почти единогласно голоса противъ этого рода предпріятія, Однимь ивъ противниковъ операціи для остановки кровотеченія вскорб посль разрыва мбшка быль Veit, при чемь онъ говориль, что не нашель въ

1) Monatschr. f. Geb. B. XIII, стр. 87.

$\left.{ }^{2}\right) \kappa_{ъ}$ ученію о внъматочной беременности 1886 r. изъ акуш. клиникц проф. К. Ф. Славянскаго.

3) Си «Врачъ 1893 스으 1, 2 и т. д. 
литературњ ни одного случая, гд屯 бы этимь путемъ спасена была жизнь больной.

Времена теперь измьнились, и по статистикь, собранной $\boldsymbol{h}$. Змигродскимб, мы видимъ, что въ 20 случаяхъ лапаротоміи при разрывъ мъпка, только 9 окончились смертью.

Lawson Tait ${ }^{1}$ ) въ теченіе 1884 и 1885 годовъ оперироваль 5 разь и въ 4-х' получиль благопріятный результать.

Эти данныя конечно значительно ободряють къ производству ранней операціи, хотя далеко еще не всь врачи въ этомь отношеніи согласны между собою.

Къ числу горячихъ защитниковъ ранней лапаротоміи принадлежить $\boldsymbol{S}$ chwartz $^{2}$ ), который пропввель лапаротомію у больной-настолько слабой, что при разръзъ брюшныхъ стьнокь буквально не вытекло ни капли крови и больная скоро оправилась оть schok'a, a затьмь выздоровъла. Вь дебатахъ по этому вопросу принимали участіе многіе выдаютіеся гинекологи Германіи: Veit, Wiedow, Martin, Frömmel, Winckel, Löhlein п др.

При этомъ интересень факть, отм'чченный Wiedow’ымъ, что въ громадном' большинствб случаевъ эктопической беременности при попыткахъ къ извлеченію мъпка наруліу, миииокв рвалсл.

Плля насъ это наблюденіе важно потому, что какъ видно изь описанія пропзведенной мною операціи, широкая связка очень легко переръзывалась лигатурами, что служило больпою помихою для остановки кровотеченія.

Относительно гоказаній кь операпіи при описываемых' нами условіяхъ, я повволю себъ привести еще мн'ьніе H. Fritsch'a $\left.{ }^{3}\right)$. Говоря о показаніяхъ при эктопической беременности прежде разрқза м'ьшка, онъ держится того, что разь діагнозь ея установленъ, всегда сльдуеть приступить къ операціи. Гораздо труднже ржпіить вопрось въ случаяхт угрожающаго жизни кровотеченія, когда врачь вастаеть больную съ высокой степенью анеміи, почти бељъ пульса. Съ научной точки зрћнія

1) Verhandlungen der deutsh. Geselsch., f. Gynaek 1888, eтp. 74.

2) L. c.

s) Bericht über gynaek. Oper. 1893. 
эти случаи просты, для практическаго же врача очень трудны. Научно нужно сказать себћ, что при истеченіи кровью единственнымъ раціональнымъ льченіемъ будеть остановка кровотеченія, которая можеть быть проивведена только посль лапаротоміи. Такимъ образомъ если врачъ хочеть помочь, то онъ долженъ приступить къ лапаротоміи.

Въ практикь дбло стопть однако иначе. Здъсь многое ржшается пе на правилахъ науки и высшей морали, а на основаній своевременности или сообразуясь сь обстоятельствами (opportunität). Такъ нбкоторые ивъ старыхъ врачей, обръзавшись на неблагодарности людей, недовърчиво относящихся къ новымъ методамъ, которыхъ они не понимають, руководствуются при льчченіи тьиъ, что въ данное время сдьлать легче. Они отстранягося оть активнаго вм'шательства и говорять, что им' никто не сдћлаеть упрека, если больная, какъ оть удара молніп, умреть въ 24 часа; при дурномь же исходь операпіи публика обвиняеть врача въ неправильномт льчченіи. Кром' того почти каждый практикъ видаль прежде случаи произвольнаго выздоровленія. 'Такъ самъ Fritsch видьль прежід случаи разрыва трубной беременности, гдь больныя оставались чалце жить, чъмъ умирали. На этом'ь основаніи нъкоторые врачи, основываясь на свомь опытћ, будуть правы, отвергая операцію.

$И$ не смотря на это, по мнбнію Fritsch'a, при угрожающемь жизни кровотеченіи сльдуеть настоятельно совътовать операцію, потому что если это не удавалось прежде, то причиною служила неизвъетность пути спасенія. Теперь извъстны многія дгжины случаевь, гды жизнь спасена лапаротоміей. Выздоровленіе достигалось въ отчаянныхъ случаяхь, несмотря на отсутствіе пульса, на невозможность оперировать чисто, несмотрл на то, что, всльдствіе нео ходимости торопиться, приходилось оставлять большое количество кровяныхь свертковъ. Такимь обравомь теперь враив будеть смотрбть неправильно, если не укажеть умирающей пути къ спасенію и не попытается спасти ее.

Я привел'ь слова Fritsch'a, сь которымъ въ настоящее время вьроятно согласно большинство гинекологовъ. По нашему мнбенію, врачъ при ветрбчё сь такими случаями, 
хотя в' принципь и будеть держаться оперативной помоши, но кром' индивидуальности каждаго отдъльнаго случая должень будеть принимать во вниманіе и другія условія.

Благодаря любезности прозектора патологической анатоміи Московскаго университета $M$. $H$. Никиоборова я получиль оть него сльдуюшее описаніе препарата оть нашей больной.

«0нъ представляетъ изъ себя грушевидной формы, величиною въ куриное яйцо, кусокъ ткани, микроскопически напоминающій собою мезомегрій, богатъ тонкостьнными сосудами, покрытъ снаружи гладкой серозной оболочкой; у болье пирокаго конца его находигся погруженная на 1 ск. въ ткань куска, рыхлая, ворсинчатая, напоминающая своимь строеніемъ дьтское мьссто, масса, съ щротивуположной стороны сбоку куска прилежитъ п далье сливается съ его тканью, кругловатаго очерганія, длиной сантиметра полтора (отръзанный на свободномъ краю) придатокъ.

«Подъ микроскопомь, ткань удаленнаго куска представ.ляется состоящеюо изъ пучковъ гипертрофическихъ гладкихъ мышечныхъ волоконъ, между к0торыми находится большое количество кровоносныхъ сосудовъ. Придатогъ оказывается фаллопіевою трубою, ворсинчатая масса-дьтскимъ мьстомъ.

«Въ куск' н'ьтъ полости, соотвьтствующей каналу матки; труба проходитг сбоку, затпмг погружается во ткань куска, но и тамг идето близко ко его краго.

«Можно думать, что удаленный кусокъ представляетъ изъ себя помьстившійся in fondo, близко къ одной изъ трубъ, узелъ подсерозной міомы, на которой пронзошло развитіе дытскаго м'ста (graviditas abdominalis). Этоть узелъ подъ вліяніемъ беременности гишертрофпровался, разросся, оттьснивъ трубку и быль удаленъ съ частью ея.

«Дать другое толкованіе въ виду неопредъленности прижизненныхъ данныхъ очень затруднительно».

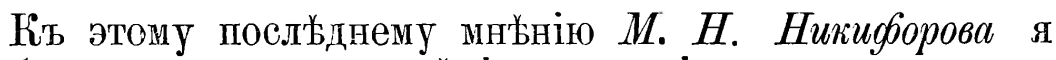
прибавлю, что къ сожальнію аутопсія произведена не была, хотя и без'ь векрытія ясно, что мы имъли дыҺло съ внвьиаточной брюоиной беременностью, при чемz зародышг прикрппился кг ббиброзной опухоли, лежавшей вб иирокой свззики.

Я уже выше сказальь, что ломкость ткани при накладываніи лигатуръ на основаніе опухоли (широкая связка) напоминала ломкость, ветрьчающуюся при влокачественныхъ новообразованіяхъ. Оказалось однако, что сд屯ланпые $M . H$. Никияборовыьмг разръзы показали, что 
ткань опухоли состояла изъ гладкихъ мышечныхъ волоконъ, тто и подтвердило предварительно высказанное мною уважаемому товарищу предположеніе, что этоть кусокь быль фиорозною опухолью. Јомкость же основанія опухоли зависълла вообце оть пзмъненій, вызываемыхъ вньмматочною беременностью, какъ это отм'ъчаеть Wiedow ${ }^{1}$ ),

Насколько мнћ извъстно, наш'ь случай представляется соверпенно новымъ. По крайней мъръ мнъ ни разу не приходилось встрћтить описанія, гдъ бы зародышь прпкрьплялея к' новообразованію. Для меня представляется интереснымъ особенно то обстоятельство, что кровотеченіе наступило только на 5-мь мъсяць беременности, потому что оно могло быть только ивь сосудов' дынтскаго мъста, прикрьпленнаго кь подиижному новообразованію. Правда, плодь быль нбсколько меньше, чйыъ указываеть больная, но этому можеть служить объясненіе, что плодъ при graviditas extrauterina всегда менъе развить. Въ нашемь случағ было весьма ясно, что зародышъ быль мужскаго пола.

Описанный случай кром' того говорить, по нашему мнънію, за раннюю лапаротомію, потому что здъсьь нб̆ть другой возможности остановить кровотеченія, кроме удаленія новообразованія, къ которому прикрьплень плодъ. Думаю, что устранить peritonitis можно также только. этимь путемь, потому что дътекое мъсто, обращенное въ полость брюшины и прирощенное къ новообразованію должно почти бевусловно вести кь погибели больной, если не будеть быстро удалено.

Такь какъ самымь непріятнымъ осложненіемъ операціи в'ь нашемь случа' оказалась ломкость ткани пирокой связки при наложеніи лигатурь, то можеть быть при подобныхъ услоіяхь лучпе прижигать ножку каленымъ жельзом' или же тампонировать кровоточащее мъсто, выводя конепь во влагалище, какъ это совьтуеть Д,. О. Отmв.

Въ общемь можно сказать, что первичная лапаротомія посль̌ разрыва плодовмъстилища представляеть всъ неудобства производства такихь операцій при неподходя-

1) L. c. 
щихъ условіяхь. Больныя же находятся въ такомъ состояніи, что о перем'ъщеніи их' в'ь спещіально-хпрургическія учрежденія не можеть быть и ръчи, а потому приходится довольствоваться тьмъ, чтобъ по возможности привести частную квартиру вь болъе или менъе подходящія кь нашимь требованіям'ь условія. Кь сожальнію, это не всегда возможно.

\title{
$\mathrm{X}$.
}

\section{НБСКОЛЬКО ЗАМБЧАНІЙ ПО ПОВОДУ ТЕРАПІИ ВЫКИ- ДЫША ТАМПОНАДОЙ.}

\author{
Юл. Ос. Аншелесъ.
}

(Читано въ засъданіи Акушереко-Гинекологическаго Общества въ Кіевъ 1892г.).

Мм. Гг.! Оставляя въ сторонб научную сторону ученія о выкидыш', получившую достаточную степень развитія въ современномъ акушерств, я позволю себъ остановить ваше вниманіе на чисто практической лишь сторонг̆ этого вопроса, касающейся терапіи выкидыша.

Сльдя ва ходомъ развитія терапевтическаго отдъљла

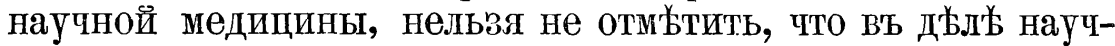
ной оц'нки методовъ врачебнаго вмъшательства теряется постепенно характеръ суб́ьективности, а таковая оцънка начинаеть становиться в'ь полной вависимости оть научнообставленной доказательности въ дъъль пригодности даннаго метода, причемъ п эта пригодность его должна быть точно по мър' возможности опредъзлена присущими показаніями и противупоказаніями. При правильной установкъ посльднихъ невольно теряется шаблонность въ методахъ л'ъченія, столь характерная для добраго стараго времени,да и въ наше еще время насчитывающая не малое число адептовъ среди врачей-практиковъ, не осмъливающихся сбросить съ себя тяжкій гнеть тысячелґтнней рутины.

Въ отдъљљ современной акуперской терапіи эта ру- 